\title{
Economic Interpretation of Philosophy of Bhagavad Gita: A Descriptive Analysis
}

\author{
Yuba Raj Pandey \\ PhD scholar at Nepal Sanskrit University
}

\begin{abstract}
Bhagavad Gita has proposed number of economic principles and values. In his recent book, The Idea of Justice, Amartya Sen discusses main massage of the Bhagavat Gita that is 'duty is important'. In addition to this, the central thesis of the Gita from the philosophical view is found through the concept of yoga. The path of action without motive (or the path of Niskam Karma Yoga) is the most important of those various principles. The path of knowledge (Gyan Yoga) and the path of commitment to work (Bhakti Yoga) are other important principles. Bhagavad Gita analyses in detail the behavioral nature of different individuals and the result of the behavior of the individual. It emphasizes on the good moral character and considers labour as the duty of each and every individual. Similarly it describes about the qualities of life and the happiness of people. Self-reliance of the individual is also emphasized in the Bhagavad Gita. Full commitment to fulfill ones assigned task makes the task successfully accomplished even if people do not care about the fruit (returns from it) before doing the task. Doubts and continuous eye in the fruit work may divert the attention of the actor from the work to the fruit only. Full concentration in the work is necessary to make the work fully successful. The concepts of sustainable development and human development also have their roots in the Bhagavad Gita.
\end{abstract}

Key words: Bhagavad Gita, Economic interpretation, Karma Yoga, Bhakti Yoga and Gyan yoga

\section{INTRODUCTION}

Many of the Western and some of the Eastern scholars including the South Asian scholars and even the political and social activities are found to be largely in the argument made by Max Weber (1930) made in his book 'The Protestant Ethic and the Spirit of Capitalism' and consider the influence of Hinduism as one of the reasons of the poverty and low rate of growth of this region. On the other hand, many of the South Asian scholars and religious thinkers believe that Hindu treatises are able to show the best possible way of progress or development of the society and the reason of the poverty and the low rate of income growth of this region is not other than their unwillingness to adopt the values and principles prescribed by the ancient treatises of this region. Thus, whether the Vedic values discourage people to work for the development of the society or the Vedic values are useful to accelerate the process of 
development is an important question or issue that needs to be solved with the help of necessary research. Bhagavad Gita is considered the essence of Vedic philosophy.

Therefore, economic interpretation of the Bhagavad Gita may be very useful to find out whether the values recommended by Hindu treatises have negative impacts in the development of this region or the reason of the low rate of economic growth and development of this region in because of the unwillingness of the countries of this region to adopt the economic values and principles of these treatises. Although Bhagavad Gita has been interpreted by many individuals in the past, any research or study fully centered in the economic interpretation of the Bhagavad Gita has not been made until today. That is why this research has been initiated and it tries to find the answer of this question.

Economic interpretation, in this analysis refers to the interpretation of the economic teachings of the text, based on the several values and principles of Economics and the general definition of economics as the study of how societies use scarce resources to produce valuable goods and services and distribute them among different people (Samuelson \& Nordhous, 2005). Bhagavad Gita is composed of seven hundred verses in total. These different verses proposed different social and human values and principles including the managerial and economic ones. This study is focused in the identification and analysis of the economic values and principles proposed by the Bhagavad Gita. Bhagavad Gita is generally considered a spiritual text by people. But some people believe that each and every issue including the economic problems of the modern world can be solved by the application of the teachings of Bhagavad Gita in real practice in the real world (Hee, 2007). But there are some people who argue that the relative low rate of development in societies like Nepal and India is due to influence of fatalistic Vedic philosophy. Such argument is basically based on the argument made by the Western thinker Max Weber few decades ago. Economic values and principles proposed in the Vedic philosophy have not been identified and analyzed in detail. Therefore the identification and analysis of the economic teachings of Vedic philosophy is very necessary and important even today. Bhagavad Gita is considered the essence of Vedic philosophy. That is why, this research on the economic interpretation of Bhagavad Gita has been made.

Therefore, the objective of this study is to provide economic interpretation of the Bhagavad Gita through the application of economic way of thinking implicit in the various translated versions of Bhagwat Gita in English, Nepali and Hindi and original version in Sanskrit, and primary data collected from policy makers, researchers and development practitioners. 


\section{LITERATURE REVIEW}

Recent years, the philosophers and researchers are interested to demonstrate the interpretations of Sanskrit literature such as Vedas, Upanishad, Bhagvad Gita among others. Over the centuries many renowned scholars and philosophers from all over the world have commented on the Bhagavad Gita and elucidated it's teaching in many publications and lectures (Satpathy \& Muniapan, 2008). For example, in his recent book, The Idea of Justice, Amartya Sen, among other things, discusses the debate between Krishna and Arjuna from the Bhagavad Gita and proposes main massage of the Bhagavat Gita that is 'duty is important' (Sen, 2009). He shows that the Gita is actually a good example of the importance of introducing impartiality into one's decision-making process (Anderson, 2012). The Bhagavad-Gita is a sermon given by Sri Krishna to Arjuna regarding the correct technique of life (Dharmaratnam, 1987). Philosophers gave the Bhagavad- Gita a central place in their reinterpretation of eastern philosophy or Hindu doctrines, necessitated by important social and cultural changes (King, 1989). Several papers show how the philosophy the Bhagavad Gita can be adopted for the improvement of modern business excellence activities (Kanji, 2003; Sharma \& Talwar, 2007; Satpathy \& Muniapan, 2008) and how it can be applied in economic development and justice (Tyndale, 2000; Sen, 2000, 2005, 2009). The Bhagavad-Gita came to be read in a new way as both a religious treatise and a national tract which emphasized action more than renunciation and taught social justice and service to others as religious duty (King, 1989). The Bhagavad-Gita has exercised an enormous influence, which extended in early times to China and Japan and lately to the western countries (Satpathy \& Muniapan, 2008).

Gita Tatparya (Essence of Bhagavad Gita) is one of the famous book written by a famous Nepali Spiritual Teacher Swami Ishwaranda has the explanation of each and every verses of Gita (Iswarananda, 2072). Das (2009) explained the economic aspect or the economics of Gita by indicating that philosophy of Gita is an instrument to solve the economic problem. Bhagavad Gita: Economic Development and Management written by Shrivastav (2003) explained positive and negative implication of the philosophy of Bhagavad Gita. Negative implications are found because of lack of proper understanding of the philosophy.

The Bhagavad Gita is an encyclopedia of life and its central theme is dharma meaning occupational duty, righteousness and virtues. It deals not only with dharma but also artha, which is the acquisition of wealth, kama which is the enjoyment of pleasures and moksha which is the liberation (Satpathy \& Muniapan, 2008). The Bhagavad Gita played an important role in developing nationalism and the movement of for political movement and emphasized action more than renunciation (King, 1989). 


\section{RESEARCH METHODOLOGY}

\section{Research Design}

The study is an analytical descriptive study of Bhagavad Gita. The process involves a review and analysis of literature on philosophy of Gita and also the interpretation of selected verses of the Bhagavad-Gita in the context of economics. "What is and what is the meaning of this from the economic perspective" is the primary method of interpretation of the Bhagvat Gita while reading the quotes from the Gita. Similar to the paper written by Satpathy and Muniapan (2008), the methodology used for the interpretation in this paper is hermeneutics. Hermeneutics is widely applied in many field of social science such as economics, law, sociology and also international relations, can be described as the interpretation and understanding of ancient literatures.

\section{Conceptual Framework}

This paper is based on thoroughly analyzing the text of Bhagavad Gita and its English, Nepali and Hindi translations and then identifying its economic values and principles and makes their interpretations. Document analysis is the primary work while doing interstation of Bhagvat Gita and this is supported by qualitative and quantitative data collected form primary survey. Interpretations made by different commentators also are used as data and materials for this interpretation. Triangulation that is a method of investigation to produce understanding from different data sources is used for this study. Following conceptual framework is used to produce economic interpretation of Bhagavat Gita.

Figure 1: Conceptual Framework of the Study

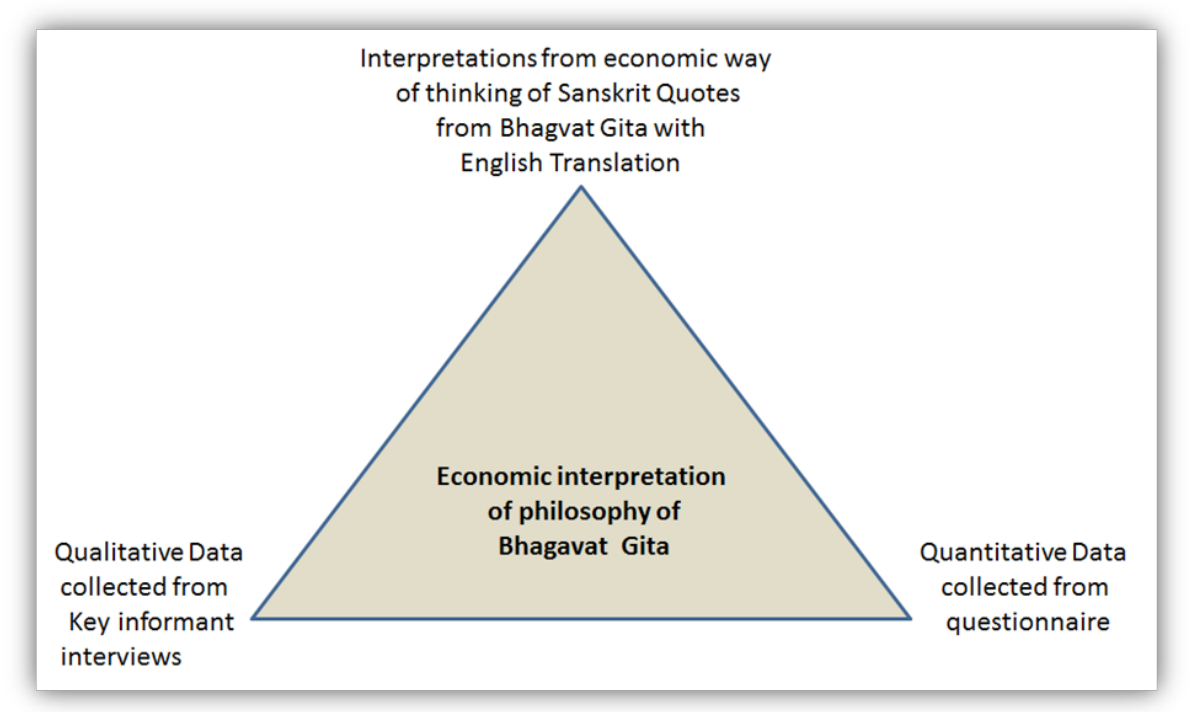




\section{Data Sources, Sample Size and Data Collection}

Both secondary and primary data were collected. Secondary date were collected books and documents, and articles from different libraries primarily located in Kathmandu, published papers in national and international journals from the websites. Some of the books and other material were collected from individual contact and networks. The materials written Nepali, Sanskrit, Hindi and English languages were used for this analysis.

For the primary data collection, both quantitative and qualitative approaches were used. At first, we developed a list of people, who were associated with different sectors including economists, policy makers, planning commission members, businessmen, professors, journalists, intellectuals, writers and among others from different sources such as Universities, Government offices, Newspapers, associations and among others. A total of individuals in this list were 400 . Fifty percent respondents were randomly selected as the sample size. Quantitative data were collected through administration of questionnaires to randomly selected 200 respondents with replacement method from the list of 400 people. The questionnaires cover basic knowledge of Bhagvat Gita, philosophy of Bhagvad Gita from economic perspective or economic way of thinking to look at the Bhagvat Gita, interpretation and application of in the present situation. For the qualitative data, in-depth interviews were carried out with key informant interviews (KII). Key informants were purposively identified from among the national distinguished personalities including two former prime ministers, two formal speakers of the parliament, four vice chairmen of National Planning Commission, two former governors of Nepal Rastra Bank, four professors of economics, two industrialists, and two religious leaders. A total of 20 key informants were selected for in-depth interviews. All key informants have basic knowledge about the Bhagvat-Gita.

\section{Data Analysis and Interpretations}

Document review and analysis procedures were used while analyzing the data collected from secondary sources. Qualitative approach was used. Themes were developed, interpretation and reinterpretation were made and validations were done through interactions with thesis supervisor and experts. All quantitative data collected through administration of questionnaires were entered into the SPSS- statistical software and descriptive results were produced. All interviews were recorded and transcribed in Nepali language. Main themes from transcribed document were selected and translated to into English language. The essence of these various source of information are the bases of this interpretation. 


\section{RESULTS AND INTERPRETATIONS}

\subsection{Economic Values and Principles of the Bhagavad Gita}

While making interpretation of Bhagavad Gita, it is not based on economic jargons such as opportunity cost, employment, economic growth, scarcity of resources that are used in the Bhagavad Gita. In fact, these jargons might not be found in the Bhagavad Gita. Interpretations have been made on the basis of consciousness and relationships between the people and between people and the earth. These are the things that are the most real to us and that give meaning to our lives. Consciousness, perceptions, thinking and behavior influence way of life of the people. Those influences and behaviors are very visibly displayed in economic behavior of the people, all of which are thoroughly explained by reference to the teachings of the Bhagavad Gita (Das, 2009). Philosophy of Bhagavad Gita shows us the way to a life in harmony with our environment. The philosophy can also be applied in business, industry, education, economics among others (Kanji, 2003). Bhagavad Gita is useful for a better understanding of specific managerial issues such as quality management (Sharma \& Talwar, 2004). The Bhagavad Gita is the debate of Arjuna-Krishna. The debate indicates three things as discussed by Andorsion (2012) in his paper. First, Arjuna was actually less concerned with issues of comprehensive outcomes. Second, Arjuna was actually not even making an argument for any particular position, but was instead rationalizing his lack of nerve and emotional weaknesses regarding the ensuing battle. Third, while Krishna does advocate doing one's duty Further, Krishna is concerned with consequences it is just a question of which consequences are the important ones.

There are many themes in the philosophy of Bhagvad Gita but the three central themes are Karma, Bhakti and Gyan (Mascaro, 1962). As defined by Kanji (2003), the word Karma has its root in the Sanskrit 'Kris', meaning to create or creation. Creation is the beginning of a journey towards a future existence, requiring effort, work and selfcontrol the whole way. Bhakti, the devotion to work, is the bond or union between people while Gyan provides the knowledge leading to the vision and joy of ultimate achievement. The information collected shows that the following different principles included in the Bhagavad Gita are the major economic values and principles of the Bhagavad Gita.

\section{Karma or Action/Work in the Bhagavad Gita}

Economic interpretation of the Bhagavad Gita is not other than the interpretation of its major values and principles related directly and indirectly with the production, distribution and consumption of goods and services. The Principle of Karma Yoga (The Principle of Action) provided by the Bhagavad Gita is its major principle related to economics as it is related directly with the production primarily the and then to 
consumption, distribution and various other values and principles like the principles of the Path of Knowledge (Gyan Yoga) and the Path of Devotion (Bhakti Yoga) also are related with the economics as knowledge and (education and technology) devotion are both necessary for various works.

Economics deals primarily with the production, distribution and consumption of goods and services which are required by people and the society. Without any action we cannot produce any goods and services. Therefore Bhagavad Gita recognizes properly the importance of action and work or describes in detail the Karma Yoga or the Path of Action, as production of goods and services creates income and the creation of income increases the purchasing power of people and society to fulfill their needs. Therefore the Karma or action is the basic requirement of the wellbeing of people and the economy and of the overall development of the society. Intellectuals like S. Radhakrishnan consider the formulation and explanation of the doctrine of action (Doctrine of Karma Yoga) as the purpose of the Bhagavad Gita (Radhakrishan, 2014). So that the doctrine of action becomes the reason and result of the economic development of a society. We can consider the Principle of Karma Yoga (Principle of Work or Action) as the basic foundation of the concept of economic development of a society. Krishna told to Arjun that he must give priority to his duty (Sen, 2009). As the Bhagavad Gita is the advice of Krishna to Arjun so as to make him ready to perform his assigned duty or work, the major objective of the scripture is not other than to teach people about the need and importance of work and the creation of income and wealth. The first six chapters of the Bhagavad Gita are mainly focused in describing the doctrine of action (Karma). A major part of the message consists in stressing the path of karma-yoga, the way of selfless action and work for others, performed in a spirit of inner renunciation by not seeking any reward or fruits of one's action (King, 1989).

Bhagavad Gita described the need and importance of work (action or Karma) in the following quotes:

- "Do thou thy allotted task; for action is superior to inaction; with inaction even life's normal course is not possible" (Gandhi, 2009,p. 70).

- "From food springs all life, from rain is born food; from sacrifice comes rain and sacrifice is the result of action" (Gandhi, 2009,p.79)

- "It was even by works that Janaka and others attained to perfection" (Radhakrishnan, 2014,p. 159)

- "There is not for me, ..., any work in the three worlds which has to be done nor anything to be obtained which has not been obtained; yet I am engaged in work." (Radhakrishnan, 2014,p. 161) 
The above statements explained about the need and the result of action. The doctrine makes it clear that living being cannot even live without work. This means that people need to work to fulfill the needs of too. Life is sustained in the world if living beings take food, and food grains grow if there is rainfall. Bhagavad Gita uses the term 'yajna', means 'Sacrifice'. The word 'yajna' means 'all actions performed for the goods or service of others' by 'refraining from causing sufferings to other creatures' (Gandhi, 2009, p. 72). Thus the terms 'sacrifice' refers here to the action without motive or selfless action. It clearly states that the food, that is, the production, is the result of human work. In Gita, Krishna recognizes the various types of works or jobs of human beings, therefore the term 'food' in this verse can be considered symbolically used to refer to all types of goods and services produced by people through their work.

In the twentieth verse of chapter three, Krishna says that Janaka and other prominent personalities who attained perfection in their life have obtained that perfection by their work. Thus, Krishna describes the importance of work.

Again, Krishna gives his own example to show the need of action for each and every individual. He says here that he is constantly working in his life even if there is not anything that he has not attained yet. It means that he considers the work as the duty of life and he will continue to do his job always till his end. In the twenty third and fourth verse of the same chapter, Krishna says that if he did not engage in work, people will follow his path and they would fall in ruin. Before that in the Twenty first verse, Krishna that says. "What so ever a great man does, the same is done by others as well."

Thus Bhagavad Gita presents a picture of a dynamic society and the world in which all individual who are able to work become engaged in work appropriate for them. Thus, Bhagavad Gita sees the necessity of full employment and in a country a society to make them able to produce maximum possible, and optimum level of output.

Gita does not say that the fruit depends upon the fate, and there is no need to work. The treatise does not also indicate and explain that the fruit of the work is received by the individual only in the next birth. Some misinterpretations have been found in the works of western writers. Gita asks people to do their work without having any doubt in the fruit with full devotion (Adhikari, 2071). Inputs are in your control but not the results because results are determined by many other factors. So Gita asks people to work with full attention without any feeling of self-right in the fruit of one's action and without the strong expectation or the hope of the fruit. In summary, Gita suggested to people to work with full attention by enjoying the work itself and people should not remain idle or inactive or without action even if they cannot get the expected result 
due to other responsible factors (Ishwarananda, 2072, p. 101). It says that one who takes both success and failure with an indifferent mind is yogi and defines such evenness as the Yoga (Radhakrishnan, 2014). Thus performing action without attachment to fruit creates even mind in the success or failure to get the fruit is called the Yoga by the Bhagavad Gita. The chapter 18 of the Bhagavad Gita suggests people to be devoted to one's own duty selected on the basis of the very nature or innate capacity or quality of the individual. The translation of the verse in as given below:

"It's better to perform one's own duty modestly

than to perform someone else's duty well.

The one who works in line with one's own nature

is not likely to wear any sin." (Baidya, 2071)

There are Sanskrita words 'Swadharma' and 'Paradharma' used for the duty. The word 'Swadharma' is 'one's own duty'. The work that fits with the nature (Swabhava) of that individual is called the duty of that individual. The work not fitted to the nature of an individual means 'someone else's duty' (or Para-dharma or other's duty). Thus, this verse clearly shows that to perform our own duty is better for us than to perform another's duty. The critics argue that the term 'Swadharma' (One's own duty) defines the duty defined according to the Verna system (or the system of ancient division of labour) and blame Vedic philosophy as supporting the caste system. But, division of castes relating to the ethnic connection of individual is quite different from the real meaning of Verna system as described in the Vedic philosophy as described in Vedas and Bhagavad Gita. Gandhi also has the opinion that the Sanskrita term 'Swadharma' refers to 'one's own duty', but not the caste (Gandhi, 2009, p. 263). Thus Bhagavad Gita says that people should employ their minds in tasks or works that are not alien to their nature. Thus, Bhagavad Gita has not said in any of its verses for and about the allocation of tasks among people on the basis of their castes. Bhagavad Gita and Vedas have not defined anywhere Verna system as the caste system. Therefore, referring Verna system as the caste system by some interpreters and critics of Vedic philosophy is not other than the misinterpretation made either by ignorance or by biasness towards this philosophy and culture.

Critics of philosophy of Bhagavad Gita often argue that this philosophy glorifies renunciation of work, and as a result, the region under the influence of this philosophy is economically backward. This argument is also based on the surficial study of the Hindu tradition and the philosophy. The Bhagavad Gita is sufficient to prove that the renunciation of work is not the ideal of Hindu householder. 
The objective of Bhagavad Gita is not to restrict any action, or any choices, it just demands from its actors 'to exercise their choices in an enlightened manner (Banerjee, 2013). According to Gita, every individual acts under the influences of three gunas' (forces, innate qualities) 'namely Sattvika (that which is saintly) Rajasika (that which is kingly) and Tamasika (that which is sinister). Though every individual in every situation will act in consonance with all the above forces, one of the above mentioned forces (nature) appears more dominant in the individual. The Bhagavad Gita advises that 'every entity' having the interest of perfection in life (moksha/nirvana) must 'try to predominate his actions with the Sattvika guna' (nature of goodness), 'then to Rajasika guna' (nature of passion)' and the Tamasika guna (nature of dullness or ignorance) 'in order' (Banerjee, 2013).

Thus, the economic behavior of the individual has large influence in the economy of a society and the Bhagavad Gita tries to influence people to make them ready voluntarily to conduct good, honest and fair economic and social behavior to increase happiness in people and the society.

\section{Consumption and Distribution in the Bhagavad Gita}

Consumption in general terms, refers to the act of using energy, food and other materials. Consumption and production are two sides of the same coin. Goods and services are produced for the consumption purpose. Production and consumption are discussed at the same time in the philosophy Bhagavad Gita. Those who use goods and services to satisfy their desires or demand are consumers. Similarly, the process of storing and transporting products is known as distribution. Both the consumption and distribution are the important dimensions of an economy. Bhagavad Gita has specific directions on the consumption and production of the individual and the government.

Bhagavad Gita asks people to work both for the service of others (for the distribution) and to fulfill or satisfy self-life necessities. The twelfth verse of the chapter three of Bhagavad Gita is translated in following words:

- Fostered by sacrifice the gods will give you the enjoyments you desire. He who enjoys these needs without giving to them is verily a thief (Radhakrishnan, 2014, p. 155)

Bhagavat Gita takes the terms 'yajna' to mean the work done for the service of others. The term sacrifice also means the same. Gandhi explains the first part of the verse and describes that this part means that if anyone works 'for the service of others' 'the gods in the form of society' gratified by the bodily labour of that individual will gratify the 'desires' of that individual or the gods in the term of society will bestow upon 
the individual 'the desired boons' (Gandhi, 2009, p. 79). The second part of the verse means that if anyone who receives what the society gives to that individual but doesn't do bodily labour for the good of the society is a thief.

Thus this verse clearly indicates that an individual needs to distribute his production both for the self-consumption and for the benefit of the society. Thus Bhagavad Gita demands from the people to invest reasonable portion of their production or income in the service of others. This investment can also be made for the construction of social infrastructures or in the form of providing service to the society or other people.

The thirteenth verse of the same chapter further elaborates this subject. The good people who eat what is left from the sacrifice are released from all sins but those wicked people who prepare food for their own sake verily they eat $\sin$ (Radhakrishnan, 2014, p. 155).

Thus those people who eat what is left behind after the 'yajna' or the service of others in over 'become free from all sins.' Those people 'who cook food only for themselves, who work only for selfish ends, take in nothing but sin when they eat'. Therefore, 'we should regularly and daily perform' work for service of the society or yajna or make a sacrifice of which body labour is the foundation'(Gandhi, 2009,p. 79).

Thus, thirteenth verse asks people to prefer the service of others than to satisfy the personal desires. But it does not mean that an individual should not give preference to his life needs, every individual should fulfill his life needs from his labour. Support or help the poor, elders and other needy people also can be taken as one dimension or part of the service of others or the service of the society.

\section{Division of Labour (Verna System) in the Bhagavad Gita}

There is 'Verna' system used by Krishna in Bhagavad Gita. Critics of Hindu philosophy interpreted the ancient Verna system as equivalent to the caste system in the present society. But such interpretation is not based in the real study of the scriptures.

From the ancient times, the professions in this region of the world were classified in four broad categories of profession on the basis of their innate qualities (Shukla, 2007, p. 94). The four categories of those four different classes are as follows:

i. Brahman/Brahmin - (Teacher, Spiritual leaders, priests and advisers and experts of every discipline) (Shukla,2007,p. 98) 
ii. Kshatriya - (Class of people that protect.- 'Rulers Civil Administrators, army and police personnel')

iii. Vaishya - (The business and farming class- 'Cultivation, cattle rearing, business, trade, finance and industrial activities) - (Shukla, 2007, p. 100)

iv. Shudra - 'Service providers class'- Shukla, 2007, p. 100) or the worker class.

Krishna in the forty first verse of the Bhagavad Gita says that these four classes are determined on the basis of their qualities or nature. He says:

"The activities of Brahmins, the Kshatriyas, the Vaishyas and the Shudra have been divided in accordance with the qualities of their nature" (Mehta, 2007, p. 57)

Here, the activities thus determined are considered the duties of the related profession. In modern times also, people select profession according to their interest and their efficiency and skill in the work.

We have seen that the government and private companies select people for different provisions on the basis of specific related qualifications, skills and experience. Similar was the Verna system described in Bhagavad Gita and Vedas. It is the misinterpretation made by different types of vested interest of the elites in the society that gave rise to caste system, in course of time, which is again losing its influence gradually in the society.

To sum up, the Verna system was the system of the division of labour in a society. We see that division of labour is one of the basic features of every economy.

\section{Path of Knowledge in the Bhagavad Gita}

Samkhya Yoga (Yoga of understanding) and Gyan Yoga (Yoga of Knowledge) are the two of the important doctrines forwarded by the Bhagavad Gita. 'Samkhya philosophy is based on knowledge; the path of Samkhya is the path towards ultimate knowledge'(Osho, 2012, p.359). Osho further adds 'according to Samkhya, knowledge is enough onto itself. We do not need to do anything else - understanding is enough. The despair and bondage which are prevalent in the world today are nothing else but ignorance - lack of true knowledge. There is no greater bondage than ignorance' (Osho, 2012, p. 360). We have to get true knowledge from our experience. Thus the knowledge Samkhya talks about is direct knowledge to overcome ignorance. All that matters is to know who I am, and to know shot surrounds us from all sides' (Osho, 2012 P. 360). 'The scholastic version of the Samkhya is a frank dualism of purusha (self) and prakriti (not self) which is transcended in the Gita, which affirms the reality of a Supreme Self' 
(Radhakrishnan, 2014, p.130). The fourth chapter of the Bhagavad Gita describes in detail the way of knowledge. Krishna here emphasizes.

Krishna compares 'to know' with the 'yajna' or the 'sacrifice'. The verse is as translated below:

'Knowledge sacrifice is better, O Parantapa, than material sacrifice which does not bind finds its consummet in knowledge (Gyan) (IV-4) (Gandhi, 2009, p. 33)

Thus, a person who performs the yajna of knowledge makes a greater sacrifice than the person who makes the yajna of money according to Krishna.

In this chapter Krishna compares knowledge (wisdom) respectively with ship that helps to cross over all evil. Even though thou be the most sinful of sinners, thou shall cross the ocean of sin by the boat of knowledge (IV-36). (Gandhi, 2009, p. 38)

Knowledge here refers to both the goal of perfection and the way to it. Education can be considered useful way of getting knowledge. In the thirty fourth verse of this chapter, Krishna says that 'the man of wisdom who has seen the truth will instruct thee in knowledge'. This shows that thousands of years before the modern age, Bhagavad Gita has recognized education as an indicator of human development.

\section{Social Welfare in the Bhagavad Gita}

The Bhagavad Gita asks people to work for the welfare of the world or society. The twentieth verse of chapter III uses the term 'Lokasamgraha' in the sense of social welfare. The translated version of the verse is as given below:

Many a great sage like Janaka

attained perfection by way of desireless action,

so you, too, should perform your duty

bearing in mind the welfare of the world. $\quad$ (Baidya, 2071, p. 101)

Baidya (2071) has translated the world 'Lokasamgraha' to mean 'welfare of the world' and Radhakrishnan (2014) has translated to mean 'maintenance of the world'. We see that the term 'Lokasamgraha' in composed of two words - 'Loka' and 'Samgraha'. The word 'Loka' denotes, according to Agarwal (1995), 'in different contexts, either human beings or the world. The world 'Samgraha' has more than one meaning, ranging from 'Keeping together' to 'protecting' as also to 'regulating' (Agarwal, 1995, p. 296) Similarly, Tilak considers 'The most important direction of the Blessed Lord to Arjuna 
is support of the doctrine of Karma. Yoga' 'contered on Lokasamgraha' and defines it in these words:

Taking all the meanings of Samgraha as given in dictionaries Lokasamgraha means, 'binding men together, and protecting, maintaining and regulating them in such a way that they might acquire that strength which results from mutual cooperation, thereby putting them on the path of acquiring merit while maintaining their good condition (Tilak, as cited in Agrawal, 1995, p. 296)

Barend A. Van noted in the preface of Agrawal's book- 'The social message of Gita' gives, summarizing the message of Agrawal's book, gives the meaning of Lokasamgorha in these words:

"Lokasamgnaha", literally "involvement with the world, and more broadly, the willingness of people to undertake action, especially desireless action (niskamakarma) on behalf to the community in which they find themselves'.

This concept seems similar to the concept of 'social welfare' in economics, therefore, the Bhagavad Gita can be considered to have forwarded the concept of 'social welfare'. This can be regarded as the very important contribution of the Bhagavad Gita in Economics.

Bhagavad Gita is the twenty fifth verse of the same chapter further emphasizes this economic concept of social welfare and says that.

'The ignorant ones act with selfish motive. So, they are bound by their own action, but people with wisdom stay free, Ayuva, Working selflessly for the welfare of the world.' (Baidya, 2071,p. 103)

Bhagavad Gita thus asks people for the social welfare even in the individual basis. Certainly, Agrawal rightly says that it is a potentially dynamic social ideal.'

\section{Basic Needs of Life in the Bhagavad Gita}

The Bhagvad Gita considers work necessary even for the maintenance of life or to fulfill the basic needs required for the maintenance of life. This verse is translated in the following words:

Do thou thy allotted work, for action is better than inaction; even the maintenance of the physical life cannot be affected without action. (Radhakrishnan, 2014, p. 154) 
Here, the Sanskrita word 'Sharirayatra' means the maintenance of physical life. The statement that work is necessary even for the maintenance of life in itself makes it clear that other physical goals of life also cannot be fulfilled without work. Thus, the Bhagavad Gita emphasizes that certain minimum level of 'Artha' (wealth) and Kama (pleasure) have to be achieved by each for the maintenance of physical life and higher level of Artha (wealth) and Kama (pleasure) require more work.

Tilak (as cited in Agrawal, 1995) is of the opinion that the doctrine of Karma yoga includes both acquisition of the prosperity and knowledge. He further says that the Supreme God or the Kirshna himself has not left the wealth and prosperity and, therefore, human beings also can work for wealth and prosperity.

Agrawal also is of the view that although the Bhagavad Gita 'does not specifically mention all the four Purusarthas' (Goals of life) together in any single verse, they are referred to either singly or the groups of two's or three's, and the importance of each of the three is stressed in different contexts' (Agrawal, 1997, p.407). He also argues that putting aside artha (prosperity) and Kama (pleasure) completely 'does not do justice to the comprehensive practical approach of the Gita to individual goal specification' (Agrawal, 1995, p. 407).

But the Bhagavad Gita is highly concerned with the 'conditions under which the wealth is to be acquired. Acquisition of wealth by unjust means is not allowed by the Bhagavad Gita (Agrawal, 1995, p. 409). It asks people to acquire wealth by means of just means and utilize it properly. The acquisition of wealth by unjust means is referred as demoniac in the twelfth verse of chapter 16 . Limitless hankering after wealth is also condemned in the $13^{\text {th }}$ verse.

\section{Health Sector Development in the Bhagavad Gita}

Bhagavad Gita suggests people to be careful to take food that save them from different diseases. The verse XVII-7 states that Sattvika (good quality) food is useful for good health. The translated verse is given below:

"The foods which promote life, vitality, strength, health, joy and cheerfulness, which are sweet, soft, nourishing and agreeable are dear is the good' (People with good mode) (Radhakrishnan, 2014, p. 408)

Simplifying further, the ninth verse of the same chapter identifies food that promotes diseases. In such words : The foods that are bitter, sour, saltish, very hot, pungent, harsh and burning, producing pain, grief, and disease are liked by the obsessive (Radhakrishnan, 2014, p. 409). 
Thus teachings of Bhagavad Gita are basically concentrated in the prevention of diseases than the cure. It classifies food types on the basis of their positive or negative influences in the health.

Meditation is described in the sixth chapter of the Bhagavad Gita. Meditation also makes people healthy and free from stress and strains. The chapter describes both the process and benefits of the meditation. Holding the body, head and neck erect and still, looking fixedly at the tip if his nose, without looking around (without allowing his eyes to wander) (Radhakrishnan, 2014, p. 230). For the man who is temperate in food and recreation, who is restrained in his actions, whose sleep and waking are regulated, there ensures discipline (yoga) destroys all sorrow (Radhakrishnan, 2014, p. 233).

The man of stable wisdom (Sthitaprajna) described in the fifty-fifth and fifth sixth verse of second chapter is described by commentators as one of the great contribution of the Bhagavad Gita. Such a man remains stress-free and therefore healthy too. This shows that Bhagavad Gita identifies very well the importance of good health in the life of human beings.

The good health influences both the working capacity and the productivity of the individual. Thus, health development cannot be ignored in the study of development literature.

\section{Happiness in the Bhagavad Gita}

Happiness has recently been recognized by the international community as one important indicator of development of a country. But, thousands of years before, Bhagavad Gita identified the importance of happiness in society, although the indicators of happiness as identified by the modern world may not be similar with the Bhagavad Gita.

Krishna describes happiness in four verses of chapter 18 in its $36^{\text {th }}$ to $39^{\text {th }}$ verses. Individuals feel happiness in different things according to their individual modes. Thus there are three types of happiness. Happiness that springs from a clear understanding of the Self is said to be of the nature of goodness (verse 37). Happiness that arises from the contact of the senses and their objects is said to be of the nature of 'passionate' (verse 38) and happiness that arises from sleep, sloth and negligence is said to be of the nature of 'dullness' or ignorance (verse 39). True happiness of human beings, according to Bhagavad Gita, lies not in the possession of outward things but in the fulfillment of the higher mind and spirit, in the development of what is most inward in us (Radhakrishnan, 2014, p. 431). 
Thus, the availability of the higher level knowledge together with the goods and conditions that provide physical enjoyment are the two different dimensions of happiness according to the Bhagavad Gita. It is clear that fulfillment of the basic needs including food, shelter, clothing, health and sanitation, education, security of life and property, social harmony, mutual cooperation and equality and unity in people, good natural environment, availability of basic infrastructures in the society, assurance of the basic human rights and certainty of the dignity of the work can be considered some important dimensions of happiness. Autonomy, self-reliance and dignity of a country are also the factors influencing the happiness of its citizen. Human and social values prescribed by the Bhagavad Gita, is the foundation to prepare the framework of happiness of people in a society.

\section{Contribution to others in the Bhagavad Gita}

In the economic theory and the society, satisfaction or the utility of an individual is basically measured on the basis of satisfaction or utility obtained by the individual from the consumption of goods and services. In the individualistic society, individual satisfaction is thus measured or compared on the basis of satisfaction obtained through consumption. Individual tries to get maximum satisfaction from each unit of his money spent to purchase goods and services.

We see in our society that some people spend all of their income saved after fulfilling their basic needs in serving other people. For example, certain people spend their life in caring elder people of the society, whereas some other people devote their life to provide shelter and other basic needs to children staying in the roads. They don't want to collect personal property. Similarly, some other people donate all their land and whole of other property to certain shelter-houses. Those people spend their property voluntarily to such public institutions or donate their property in the service of others. These people get maximum satisfaction from such contribution to others, or to the society. Thus the traditional notion of utility or satisfaction measurement on the basis of consumption does not work in such instances. In such cases, the indifference curve does not measure or compare the satisfaction that comes from the consumption of specific combinations of the commodities but they get utility or satisfaction from the contribution that they make to others or the society. The larger they can contribute to the society, the larger satisfaction they feel or receive. The satisfaction received from the contribution can also be measured or compared as it is compared according the consumption of the combinations of the commodities.

This shows that economic behavior is not limited only to the satisfaction of individual that comes from the consumption or the purchase of goods \& services for selfconsumption, but the economic behavior of the individual who contributes to others. 
The Bhagavad Gita suggests people to devote themselves in the service of others to achieve or attain highest level of satisfaction or achievement in life. The thirteenth verse clearly says that people who eat whatever is left from the sacrifice or what is left from the service of others are released from all sins (III-13) and attain the supreme god or the perfection in life (III-II). Thus, analysis of economic behavior of people based on the level of satisfaction that is received from the contribution to others is preferred and advocated by the Bhagavad Gita and such behavior can also be interpreted by the help of indifference curve or map.

\subsection{Results from Survey Data}

\section{Principles Described by the Bhagavad Gita}

Bhagavad Gita teaches or describes about different principles like the Gyan Yoga (the path of knowledge), Karma Yoga (the path of action), Bhakti Yoga (the path of devotion to work), Dhyana Yoga (the path of meditation), Sankhya Yoga (the path of wisdom/ understanding) etc. As Bhagavad Gita teaches different Yogas (paths to be followed by human beings), it is also called the discipline of yoga (yoga-shastra). But the path of action, path of knowledge and the path of devotion are considered the major three principles described by the Bhagavad Gita. In the questionnaire, people were asked to mention which principle they think is the major principle described in Gita. Table 1 shows the responses of sampled respondents discussed in the methodology section about what they consider about the major emphasis of the Bhagavad Gita.

Table 1: Principle Emphasized by the Bhagavad Gita

\begin{tabular}{lllll}
\hline S.No. & Path (Yoga) & Freq. & Percent & Cum. \\
\hline 1 & The path of knowledge (Gyan Yoga) & 1 & 0.5 & 0.5 \\
2 & The path of action or work / duty (Karma Yoga) & 9 & 4.5 & 5 \\
3 & The principle of devotion to work (Bhakti Yoga) & 5 & 2.5 & 7.5 \\
4 & All the three principles mentioned above & 185 & 92.5 & 100 \\
\hline & Total & 200 & 100 & \\
\hline
\end{tabular}

As seen in the table large percentage of people (92.5\%) or total 185 people considered that Bhagavad Gita emphasizes all three principles and 4.5 percentage of people considered that the path of action is the most important one and 2.5 percentage people considered the path of devotion as the major focus of the Bhagavad Gita. 


\section{Development Policy Supported by the Bhagavad Gita}

All the 200 participants were asked to express their views on this issue. Out of 200 participants, total 194 participants recognized at least one development value of the Bhagavad Gita is useful and relevant to be included in the recent development policies of the countries. The values recognized by the participants are grouped in 12 different categories as mentioned in Table 2 .

Table 2: Teachings of Bhagavad Gita to be Incorporated in Development Policy

\begin{tabular}{lll} 
S.No. & $\begin{array}{l}\text { Values to be Incorporated in Policy (Development Values Advocated } \\
\text { by Bhagavad Gita) }\end{array}$ & $\begin{array}{l}\text { No. of } \\
\text { Respondents }\end{array}$ \\
\hline 1 & The principle of Karma (action) with full dedication (Karma Yoga) & 170 \\
2 & Creation of just society & 65 \\
3 & Sustainable Development & 45 \\
4 & Preference for welfare/society/state, social protection \& public interest & 43 \\
5 & Knowledge and technology development (Gyan Yoga) & 42 \\
6 & Good Governance (Rule of Law/Equality Fairness) & 33 \\
7 & $\begin{array}{l}\text { High level of moral character (moral education) and commitment to } \\
\text { ethics }\end{array}$ & 25 \\
8 & Honesty and truth & 22 \\
9 & Happiness creation & 11 \\
10 & Selflessness & 10 \\
11 & Self-reliance & 6 \\
12 & $\begin{array}{l}\text { Others(Discipline, mutual-respect, mutual-existence, peace, democracy, } \\
\text { spiritual value friendly development etc. }\end{array}$ \\
\hline
\end{tabular}

Thus, out of 200 participants only six considered that there are not any development values to be followed in Bhagavad Gita whereas $97 \%$ or 194 participants considered that Bhagavad Gita have useful development values.

\section{Development Approach Advocated by the Bhagavad Gita}

There was a question in the questionnaire about the type or strategy of development that is advocated and prescribed by the Bhagavad Gita. Table 3 shows the different 
responses people made about the type of development advocated by the Bhagavad Gita.

Table 3: Type of Development Approach Advocated by the Bhagavad Gita

\begin{tabular}{|c|c|c|c|c|}
\hline S.No. & Strategy of Development Approach & Freq. & Percent & Cum. \\
\hline 1 & $\begin{array}{l}\text { Strategy of unrestricted individual freedom for } \\
\text { economic activities }\end{array}$ & 13 & 6.5 & 6.5 \\
\hline 2 & $\begin{array}{l}\text { Strategy of banning individual freedom of running } \\
\text { economic activities }\end{array}$ & 3 & 1.5 & 8 \\
\hline 3 & $\begin{array}{l}\text { Strategy of educating people to enjoy individual } \\
\text { freedom to run economic activities for their benefit } \\
\text { without any kind of undue exploitation of others } \\
\text { and nature }\end{array}$ & 180 & 90 & 98 \\
\hline \multirow[t]{2}{*}{4} & Others & 4 & 2 & 100 \\
\hline & Total & 200 & 100 & \\
\hline
\end{tabular}

As shown in the table that 90 percent people who filled the questionnaire think that Bhagavad Gita forwards or proposes the strategy of development to educate people to enjoy individual freedom to run economic activities for their benefit without any kind of undue exploration of other people, other living beings and the Earth and the environment. The 6.5 percent of the total respondents believe that Bhagavad Gita proposes the strategy of unrestricted individual freedom. This means that 96.5 percent of the total respondents believe that Bhagavad Gita advocates individual freedom of running economic activities. This shows that the essence of classical economic development theory or the concept of free economy already existed in the Bhagavad Gita. But the development theory advocated by the Bhagavad Gita is more balanced in the sense that it demands strict restrictions on the undue exploitation of people, living beings and the nature. This shows that if the world had followed the teachings of the Bhagavad Gita, world would not have to bear the present hazards of climate change and the environmental degradation.

\section{Influence of Bhagavad Gita in the Economic Behavior}

The behavioural principles taught by the Bhagavad Gita influence the economic behavior of the people. Economic behavior of an individual can be categorized into three major categories- production behavior, consumption behavior and the distribution behavior. People believe that teaching of Bhagavad Gita have influence in all these three types of economic behavior. Table 4 shows the responses of the people about what type of economic behavior is considered influenced by the teachings of the Bhagavad Gita. 
Table 4: Types of Economic Behavior that are Influenced by the Bhagavad Gita

\begin{tabular}{lllll}
\hline S.No. & Types of Economics behavior & Freq. & Percent & Cum. \\
\hline 1 & Production & 3 & 1.5 & 1.5 \\
2 & Consumption & 1 & 0.5 & 2 \\
3 & Distribution & 6 & 3 & 5 \\
4 & Production, consumption and distribution & 190 & 95 & 100 \\
\hline & Total & 200 & 100 & \\
\hline
\end{tabular}

It is seen from the table that $90 \%$ people think the teachings of Bhagavad Gita influences all the three types of economic behaviors- the production behavior, consumption behavior and distribution behavior of people.

\subsection{Results from Qualitative Information}

The qualitative data collected from KII are presented as follows:

"......... teachings of Bhagavad Gita are focused mainly on three issues - knowledge (Gyan) work (Karma) \& devotion (Bhakti). Bhagavad Gita describes the rules to be obeyed by people in their life. It asks people not to earn money value by abandoning the broad human values. Bhagavad Gita talks about human values."

A writer

“..... development model and culture of a country have close relation. Bhagavad Gita is not only a spiritual scripture, but is also a book on life management, stress management........ Bhagavad Gita does not promote fatalism, but promotes intelligence. .........Bhagavad Gita believes in work and therefore its philosophy is 'activism' - individual activism or the work centric philosophy. It is against escapism.

A Swami (Osho leader)

“....... Civilization cannot be developed in poverty but can only be developed in prosperity. When man becomes free from the problem of food and shelter; then he starts to think about the happiness and about the improvement of his life. ......only man starts to think about art and culture. Development of art and culture is possible only in the foundation of economic prosperity....." 
Former Prime minister

"...... Cultural factor is one important determinant and the dimension of production function. The relation between production function and cultural factors is found. The culture of a country is influenced by the dominant religion and the ancient religious treatises like Bhagavad Gita of the country......"

\section{A professor of Economics}

"....... some of the values and principles of ancient treatises might have been misinterpreted by people knowingly or unknowingly. So, if there are development friendly values, principles or teachings in Bhagavad Gita and other ancient treatises, we can interpret them rightly....."

Former Member of National Planning commission

"........ Bhagavad Gita is a philosophy. The duties to be fulfilled and behaviours expected by people are described very well by the Bhagavad Gita..... The centre point in the Gita is that it asks people to fulfill their duty without being influenced by the relatives and family members. ...... The doctrine of action without motive - is the doctrine of action, it does not encourages passiveness or idleness, but promotes action. It only asks people not to expect result larger than the action itself. ....."

\section{Former Governor}

".......all three types of Yogas forwarded by the Bhagavad Gita are important. The choice among these three depends on the nature of the individual. The third \& fourth chapters of Bhagavad Gita concentrated mainly in work are more useful for extrovert and active people....."

A Swami (Osho leader)

Bhagavad Gita is not a development unfriendly document, rather it is development friendly. The fact shows that the philosophy of Bhagavad Gita is very relevant in the modern economics. The Bhagavad Gita advocates economic freedom for people but it appears in favour of strong regulation to ensure ethical behavior in the economic behavior of people. As the ultimate goal of the Bhagavad Gita and the religion is to create happiness in society and the goal of the development effort of a society also is to create happiness in society. Thus, we can say that the essences of the teachings of the Bhagavad Gita are relevant in designing the economic development policy framework. 


\section{CONCLUSIONS}

The Bhagavad Gita represents the many struggles, or battles, now people face many problems and have to do their responsibilities to the society. The Bhagavad Gita is useful for a better understanding of specific managerial and economic issues and focusing on issues facing economic challenges. The Bhagavad Gita suggests that Karma is work and work is life. Karma improves the core concepts of commitment (Bhakti), and embeds knowledge of economics (Gyan). The debate of Arjuna-Krishna shows a good example of the importance of introducing impartiality into one's decisionmaking process.

Some people regard it as a psychology whereas some other analysts and intellectuals consider it a book on stress management. It is also regarded us the science of yoga. Although, many people do not often consider that it has economic values and principles in it, but the most of the economic behaviours of the people in modern age also can be analyzed on the basis of its knowledge. As mentioned above, more than 95 percent people believe that Bhagavad Gita reveals economic values and understanding that are useful in designing important economic development policies of countries. Similar opinion is expressed by the distinguished personalities in their in-depth interviews about the economic and development teachings of the Bhagavad Gita. Thus, it is also a useful treatise on sociology and Economics. To sum up, it is a philosophy of the world consisting within it the glimpses of number of disciplines including science. Economic values in it are even useful to design \& guide recent development policies.

\section{Acknowledgements}

I would like to express my sincere gratitude to my thesis supervisor, Associate Professor Shiva Raj Adhikari for providing constructive comments and insightful suggestions on an earlier draft, with the errors being the sole responsibility of the author.

\section{References}

Adhikari, N. (2071).What I understand Gita (Nepali). Lamjung, Nepal: Ramakanta Adhikari

Agarwal, S.P. (1995). The social message of the Gita symbolized as Lokasamgraha. Maryland USA: Urmila Agrawal.

(1997). The social role of the Gita. Delhi, India: Motilal Banarasidass Publishers.

Sen, A. (2000). Consequential evaluation and practical reason. The Journal of Philosophy, $92,477-502$. 
(2005). The argumentative Indian: Writings on Indian history, culture and identity. New York: Picador.

. (2009). The idea of justice. Cambridge, MA: The Belknap Press of Harvard University.

Das, D. (2009). Lessons in spiritual economics from the Bhagavad-Gita: Understanding and solving the economic problem. USA:Create Space Independent Publishing Platform.

Dharmaratnam, K. (1987). Bhagavad-Gita in action. Klang, Malaysia: Nathan Publishing

Engardio, P. \& McGregor, J. (2006). Karma capitalism. Business Week, October 30.

Gandhi, M.K. (2009). The Bhagavad Gita. New Delhi: Diamond Books.

Hee, C.C.H. (2007).A holistic approach to business management: Perspectives from the Bhagavad Gita. Singapore Management Review, 29(1), 73-84.

Iswarananda, S. (2072) Gita Tatparya (in Nepali). Swambhyu Kathmandu: Gita Adhyayan Mandal

Kanji, G.K. (2003). A new business excellence model from an old Indian philosophy. TQM \& BusinessExcellence, 14, 1071-1076.

King, U. (1989). Some reflections on sociological approaches to the study of modern Hinduism. Numen, 36, Fasc. 1, 72-97.

Mascaro, J. (1962). The Bhagavad Gita (new translation). UK: Penguin Books.

Mehta, J.M. (2007). The wisdom of the Gita. Patna, India.

Muniapan, B. (2005). The philosophy of Bhagavad Gita and its relevance to human resource development in the 21st Century. International Conference on Cultural and Religious Mosaic of South and Southeast Asia: Conflict and Consensus through the Ages, 1st South and Southeast Asian Association of Study of Religion (SSEASR) Conference under UNESCO, New Delhi, India, 27-30 January

Osho (2012). Gita Darshan. Delhi: Full Circle Publishing.

Radhakrishnan, S. (2014). The Bhagavad Gita. India: Harper Collins Publishers.

Samuelson, P. A., \& Nordhaus, W. D. (2005).Economics, $18^{\text {th }}$ ed.: New Delhi: Tata McGraw-Hill Publishing Company Limited.

Satpathy, B., \& Muniapan, B. (2008). The knowledge of "Self" from the Bhagavad-Gita and its significance for human capital development. Asian Social Science, 4(10), 143-150. 
Sharma, A., \& Talwar, B. (2004). Business excellence enshrined in Vedic (Hindu) philosophy. Singapore Management Review, 26(1), 1-19.

. (2007). Evolution of "Universal Business Excellence Model" incorporating Vedic philosophy. Measuring Business Excellence, 11(3), 4-20. doi:10.1108/13683040710820719

Shukla, N. M. (2007). Bhagavad Gita \& Hinduism. Read Worthy.

Sooklal, A. (1987). The Hare Krishna movement in South Africa. Religion in Southern Africa, 8(2), 19-39

Srivastava, A.K. (2003). Bhagavad-Gita: Economic development and management. India: Abhinav Publications

Tyndale, W. (2000). Faith and economics in 'development': A bridge across the Chasm? Development in Practice, 10(1), 9-18

Vaidya, B. (2071). The Song Supreme (Bhagwat Gita).Kathmandu: Sanatan Foundation.

Weber, M. (1930). The protestant ethic and the spirit of capitalism, Routledge, First Published in Routledge Classics in 2001.

Woodham, C. E. (2000). The Bhagavad Gita: The song of Divine. New Delhi: Pilgrims Publishing. 